\title{
Use of thyme essential oil as an antibacterial agent in raw milk intended for the production of farm cheese
}

\author{
Yasser Hachana, Bessma Ghandri, Halima Amari and Ismahane Saidi
}

Received: 02 January 2019 / Accepted: 04 April 2019 / Published online: 22 June 2019

(c) Indian Dairy Association (India) 2019

\begin{abstract}
This study aims to use thyme essential oil (TEO) as an antibacterial agent in raw milk intended for the production of farm cheese and to test its effect on bacteriological and sensory quality. Antibacterial activity of TEO was first tested in vitro on four strains of bacteria known for their pathogenicity such as Escherichia coli, Pseudomonas aeruginosa, Salmonella typhimurium and Staphylococcus aureus and then in situ on the total mesophilic aerobic flora (TMAF) in raw milk used to produce farm cheese. All tested bacteria were very sensitive to TEO with a higher sensitivity for Escherichia coli, followed by Pseudomonas aeruginosa, then Staphylococcus aureus and finally Salmonella tiphymirium. In situ study showed that TEO has an effective effect on TMAF of raw milk. Monitoring bacteriological quality of TEO based farm cheese during 6 days of cold storage, revealed the effectiveness of TEO on TMAF, yeasts and moulds. Despite the good bacteriological quality of TEO-based farm cheese, the strong aroma characterizing this essential oil was not well appreciated by some tasters, which had a negative impact on the final score attributed to this cheese. Thyme essential oil can be used as an alternative solution to produce healthy farm cheese without needing heat treatment, while ensuring high nutritional value food product.
\end{abstract}

Yasser Hachana( $($ ) , Bessma Ghandri, Halima Amari and Ismahane Saidi

Animal Production Department, High Agronomic Institute of ChottMariem 4042 Susa, Tunisia

Email: hachana@yahoo.fr
Keywords: Antibacterial effect, Farm cheese, Milk quality, Pathogenic bacteria, Thyme essential oil

\section{Introduction}

Food security is one of the most important health concerns. According to World Health Organization report (WHO, 2002), 30 $\%$ of consumers in industrialized countries suffer from foodborne illness each year. Highly consumed products such as milk, can be an important source of foodborne pathogens for human health (Van Kessel et al. 2004). Human contamination occurs mainly by consuming uncontrolled raw milk (Gravani, 1999). In the United States, some reports link the consumption of contaminated raw milk, inadequately pasteurized milk or adulterated milk products with contaminated raw milk, to many cases of foodborne illness (Evans et al. 1996, Fahey et al. 1995; Fleming et al. 1985). Usually, before its use, raw milk must be subjected to heat treatments in order to destroy bacterial flora that can be harmful to consumers. Pasteurization and sterilization processes are the most commonly used methods by food and dairy industries for microorganism inactivation. However, on farm scale, these processes are quite difficult to install, not only because of their high costs, but also because of high technical skills levels and highly qualified staff requirements. In addition, several studies have reported that in general, heat treatments can cause undesirable changes in taste, color as well as nutrient losses (Balny and Masson 1993; Datta and Deeth 1999). Indeed, a moderate heat treatment can have an adverse effect on both structure and physical properties of proteins, which are first denatured and then damaged by Maillard reactions, altering the physical appearance of the product, as well as its organoleptic and nutritional quality (Mauron, 1981). Recent research has explored other methods of milk processing that have less negative effects on protein quality, such as ultrahigh pressure or ultrasonic waves. Using high pressures between 300 and $600 \mathrm{MPa}$ has proven to be an effective method for inactivating microorganisms, including most foodborne infectious pathogens (Antonio et al. 2002). South African and British dairy legislation has stipulated that ultrasound reduces pathogenic food flora to an acceptable level, even when bacterial loads are five times higher than those allowed (Cameron et al. 2009). Nevertheless, the large-scale uses of ultra-high pressure and ultrasound in the dairy industry remain underdeveloped due 
to high cost of equipments. Other future prospects consist in exploiting the natural antibacterial potential of some medicinal and aromatic plants used by humans since antiquity (Jones, 1996). Manju et al. (2017) showed that plant derived antimicrobials transcinnamaldehyde or eugenol could be successful approach as biopreservatives to control L. monocytogenes to achieve desired inactivation at small amounts in milk. Antimicrobial activity of essential oils and plant extracts has formed the basis for many applications, including preservation of raw and processed foods, pharmaceuticals, alternative medicine and natural therapies (Reynolds, 1996; Lis-Balchin and Deans, 1997). Hydrophobicity of essential oils allows them to spread into cell membrane and mitochondria lipids, rendering them permeable and thus causing a leakage of cellular contents (Helander et al. 1998; Burt, 2004). Active components in essential oil fractions have a wide spectrum of antimicrobial activity against foodborne pathogens and spoilage bacteria (Gutierrez et al. 2009). Several molecules present in essential oils have exhibited antimicrobial properties and in particular phenols, alcohols and aldehydes (Cutter, 2000). Gramnegative bacteria are slightly less sensitive to essential oils than Gram-positive bacteria (Burt, 2004). Antibacterial activity of essential oils was demonstrated in vitro studies against Listeria monocytogenes, Salmonella typhimurium, Escherichia coli, Shigella dysenteria, Bacillus cereus and Staphylococcus aureus at levels ranging from 0.2 to $10 \mu \mathrm{l} / \mathrm{mL}$ (Burt, 2004). Using essential oils in lactic acid products has increased their nutritional value, organoleptic qualities and even their hygienic status (Amirdivani and Baba, 2011). Essential oils and plant extracts are widely used in food industry to prevent possible oxidative and/or microbial degradation of food products (Tiwari et al. 2009). However, very few complete studies on the effect of these essential oils on the bacteriological quality of raw milk and dairy products have been performed. In this context, the main objectives of this work are first to evaluate in vitro antimicrobial activity of thyme essential oil on four strains of bacteria known for their pathogenicity in raw milk, such as Escherichia coli, Pseudomonas aeruginosa, Salmonella typhimurium and Staphylococcus aureus, then to evaluate its effectiveness in vivo on the total aerobic mesophilic flora of raw milk intended for the production of farm cheese, and finally to test the effect of thyme essential oil on the bacteriological and sensory quality of the produced cheese.

\section{Materials and methods}

\section{Thyme essential oil extraction}

Raw samples of thyme plant (Thymus capitatus) were freshly collected at the flowering stage from the hills of Akouda-Susa Tunisia, during February 2018. Samples were dried for 15 days at room temperature in a well-ventilated dark place. Thyme essential oil extraction was carried out by steam distillation. Thyme essential oil separated from the aromatic hydrolate was dehydrated using sodium sulfate $\left(\mathrm{Na}_{2} \mathrm{SO}_{4}\right)$ to remove as much water as possible. Thyme essential oil samples were quickly stored at $4{ }^{\circ} \mathrm{C}$ in dark conditions.

\section{In vitro assessment of the antibacterial potential of thyme essential oil}

\section{Bacterial strains}

Four bacterial strains from the Higher School of Food Industries of Tunis, Tunisia have been selected for their pathogenicity and their frequent involvement in the contamination of foodstuffs, particularly raw milk. Bacterial strains are composed of three Gramnegative bacteria: Escherichia coli NCTC 10418, Salmonella typhimurium ATCC 13311 and Pseudomonas aeruginosa NCTC 10662 and one Gram positive bacteria: Staphylococcus aureus NCTC 6571. Bacteria were kept alive on blood agar. Cultures were prepared by inoculating approximately $2 \mathrm{~mL}$ of Mueller Hinton broth with 2 to 3 colonies of each bacterium from the blood agar. Broth was previously incubated at $35^{\circ} \mathrm{C}$. Inoculums were prepared by diluting bacterial cultures in saline solution to $10^{6} \mathrm{cfu} / \mathrm{mL}$. These solutions were diluted with sterile physiological serum.

\section{Antibacterial activity}

Screening for antibacterial activity of thyme essential oil (TEO) was performed by adapting the serial agar dilution method, based on radial diffusion mentioned by Oliveira et al. (2013). Plates with $20 \mathrm{~mL}$ of nutrient agar were inoculated with $100 \mu \mathrm{l}$ of different bacterial solutions previously prepared. A $50 \mu \mathrm{L}$ volume of each dose of TEO, dissolved in ethanol, was placed in $4 \mathrm{~mm}$ deep and $6 \mathrm{~mm}$ diameter well, dug in the aseptic agar. Each dose was repeated three times. Plates were incubated at $37^{\circ} \mathrm{C} \pm 2{ }^{\circ} \mathrm{C}$ for 18 hours. Inhibition zone diameters were measured with a millimeter ruler with $0.5 \mathrm{~mm}$ accuracy. Development of inhibitory zone, identified by a clear halo, indicates the presence of an antibacterial effect of the tested oil (Smania et al. 1999). Based on the work of Oliveira et al. (2013) bacterial sensitivity to thyme essential oil has been classified according to the diameters of the inhibition halos measured as follows:

Not sensitive (-) or resistant: diameter $<8 \mathrm{~mm}$.

Sensitive (+): diameter between 9 and $14 \mathrm{~mm}$.

Very sensitive (+++): diameter between 15 and $19 \mathrm{~mm}$.

Extremely sensitive: diameter $>20 \mathrm{~mm}$

\section{In situ assessment of the antibacterial potential of thyme essential oil}

\section{Raw milk collection}

Raw milk was obtained from the dairy farm of the Superior Agronomic Institute Chott-Meriam Susa Tunisia. Samples were 
collected aseptically in sterile containers and carried directly to the animal production laboratory for chemical and bacteriological analysis.

\section{Chemical analysis}

Raw milk's chemical composition was evaluated using FT 120 Milkoscan FOSS Denmark. Measured parameters are fat content, protein content and lactose content.

\section{Bacteriological analysis}

Before testing the effect of thyme essential oil on bacteriological composition of raw milk, samples were analyzed for total aerobic mesophilic flora according to AFNOR (2013), faecal coliforms and total coliforms according to AFNOR (2009). Thyme essential oil tested doses, were 1, 2 and $3 \%$ respectively. Each raw milk sample treated with thyme essential oil was analyzed in triplicate for all types of bacteria.

\section{Cheese production}

Farm cheese was produced in animal production laboratory using a method described by Chandan (2003). First, milk was heated to $35^{\circ} \mathrm{C}$. A dose of $1 \%$ thyme essential oil (TEO) was then added. The mixture milk-TEO was carefully stirred for 2 minutes. Then, a dose of $2.5 \%$ animal rennet was added and stirred for 1 minute. Milk was left to coagulate for 40 minutes. The resulting curd was cut and mixed gently. The curd-serum mixture was filled into moulds and gently pressed by hand to remove as much whey as possible. After draining, cheese was stored at $4 \pm 1{ }^{\circ} \mathrm{C}$ for 6 days.

\section{Sensory evaluation}

Descriptive sensory analysis or scale test was carried out to assess the impact of using thyme essential oil (TEO) on cheese flavor. To this end, 50 voluntary tasters were used. To materialize their judgments, tasters had at their disposal a descriptive scale composed of several factors such as color, smell, texture, mouth texture, taste and aftertaste. For each taster, cheese produced from raw milk treated with TEO is presented simultaneously with a control cheese produced from the same raw milk but without any additives. Spontaneous attributes were used to describe the perceived differences between the two cheeses.

\section{Cheese microbiological monitoring during refrigerated storage}

Fresh cheese samples were kept at $4{ }^{\circ} \mathrm{C}$ in the refrigerator to monitor bacterial load for 6 days of storage. Microbiological analyses concerning total aerobic mesophilic flora, faecal coliforms, total coliforms, yeasts and moulds, were carried out on the day of cheese manufacture, after 3 and 6 days of storage at $4{ }^{\circ} \mathrm{C}$ according to AFNOR (2009) and AFNOR (2013) standard methods.

\section{Statistical analyses}

Analysis of variance was performed using the general linear model procedure (GLM SAS 9.3) to study antibacterial effect of thyme essential oil on microbiological composition of raw milk and farm cheese. Different means were compared with Duncan's multiplerange tests; a probability value of $\mathrm{p}<0.05$ was considered significant. All analyses were carried out in triplicate.

\section{Results and discussion}

\section{In vitro assessment of the antibacterial potential of thyme essential oil}

Antibacterial effect of thyme essential oil (TEO) was tested on four bacteria strains: Escherichia coli, Pseudomonas aeruginosa, Salmonella typhimurium and Staphylococcus aureus. All TEO tested doses showed a very significant effect $(p<0.05)$ on each of the four pathogenic bacteria. As TEO dose increases, inhibition diameter of all bacteria increases (Table 1). Inhibition diameters sizes for all used doses of TEO ranged from 14.7 to $23 \mathrm{~mm}$, clearly indicating that all tested bacteria were very sensitive to TEO with a higher sensitivity of Escherichia coli, followed by Pseudomonas aeruginosa, then Staphylococcus aureus and finally Salmonella tiphymirium (Table 1). Thyme essential oil is considered to be one of the most active essential oils on bacteria as reported by Cox et al. (2000). Indeed, its main compound, thymol, confers a strong antimicrobial activity. Moro et al. (2013) reported that TEO has shown satisfactory anti-microbial activity in vitro against pathogens and spoilage microorganisms. In addition, Burt (2004) employed doses ranging from 0.02 to $1 \%$ and demonstrated antibacterial activity of TEO against Listeria monocytogenes, Salmonella typhimurium, Escherichia coli, Shigella dysenteria, Bacillus cereus and Staphylococcus aureus. Hammer et al. (1999) showed that minimum inhibitory concentration of TEO was approximately $0.12 \%$ for Escherichia coli, $0.25 \%$ for Staphylococcus aureus and more than $2 \%$ for

Table 1 Effect of thyme essential oil doses on bacterial growth (diameter in $\mathrm{mm}$ ).

\begin{tabular}{|c|c|c|c|c|}
\hline$\overline{\text { Dose } \%}$ & Escherichia coli & $\begin{array}{l}\text { Pseudomonas } \\
\text { aeruginosa }\end{array}$ & Staphylococcus aureus & $\begin{array}{l}\text { Salmonella } \\
\text { tiphymirium }\end{array}$ \\
\hline$\overline{1}$ & $18.2^{b}$ & $16.0^{b}$ & $15.8^{b}$ & $14.7^{b}$ \\
\hline 2 & $20.2^{b}$ & $17.8^{b}$ & $18.2^{\mathrm{a}}$ & $15.3^{\mathrm{b}}$ \\
\hline
\end{tabular}

${ }^{\mathrm{a}, \mathrm{b}}$ Column means with different superscripts differ significantly at $\mathrm{p}<0.05$ 
Fig. 1 Effect of thyme essential oil dose on TAMF of raw milk

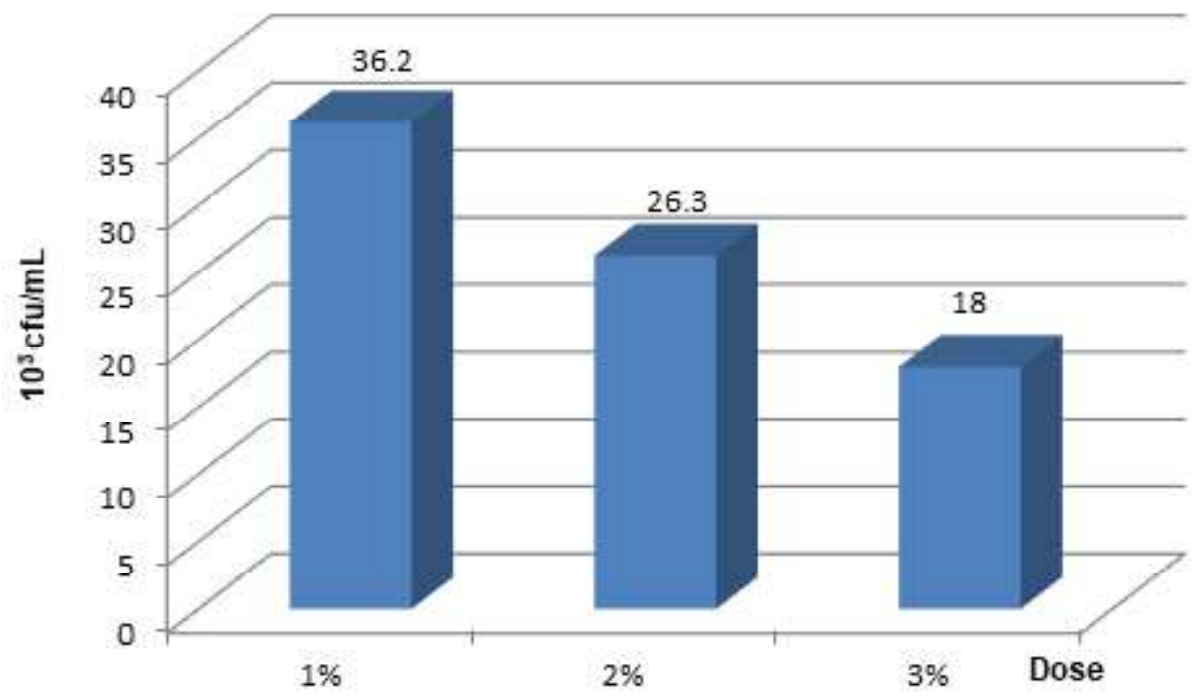

Fig. 2 Total aerobic mesophilic flor: evolution in cheese during storage at $4{ }^{\circ} \mathrm{C}$

a,b Bar means with different superscript: differ significantly at $\mathrm{p}<0.05$

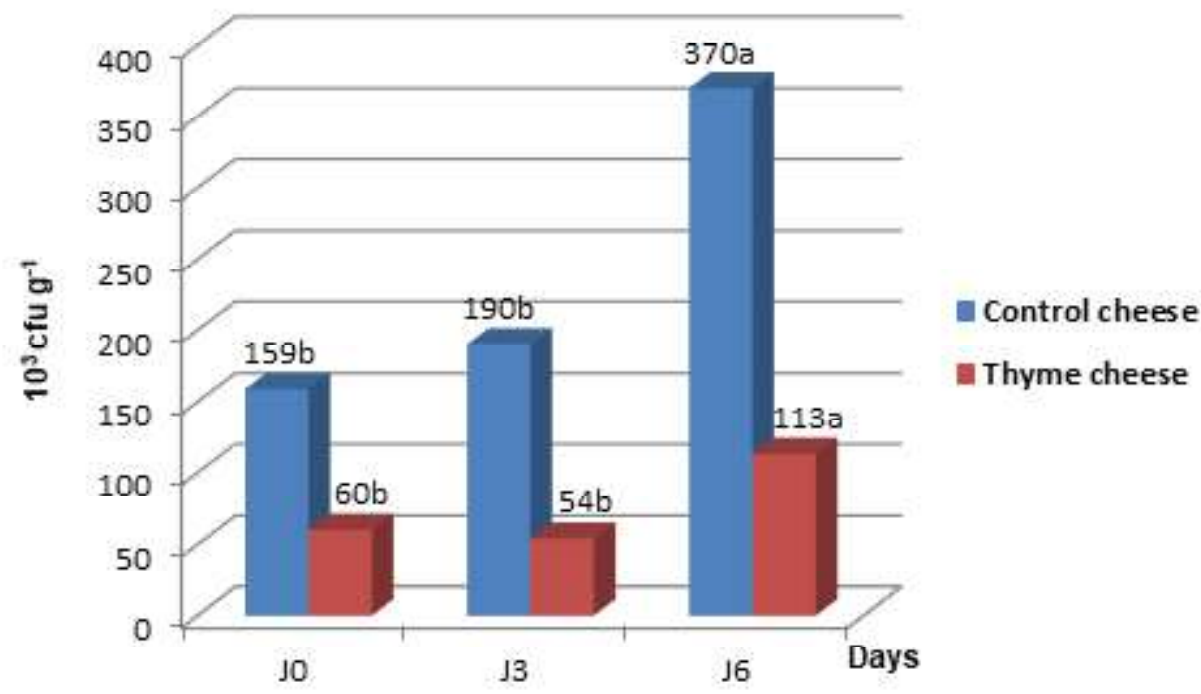

Salmonella tiphymirium and Pseudomonas aeruginosa. Burt (2004) noted that minimum TEO inhibitory concentrations generally range from 0.005 to $0.5 \%$. Paster et al. (1990) reported that TEO used at $500 \mu \mathrm{g} / \mathrm{mL}$ inhibited growth of Staphylococcus aureus and Salmonella tiphymirium, while Pseudomonas aeruginosa was not affected even at higher concentrations. Burt and Reinders (2003) and Paster et al. (1990) recorded inhibition diameters for Escherichia coli ranging from 24 to $25.7 \mathrm{~mm}$ when using diluted TEO. According to Calo et al. (2015) effectiveness of essential oils demonstrated in vitro should not be considered strictly true, due to food matrix complexity in which intrinsic and extrinsic factors interfere with activity of these compounds and must be confirmed by an in vivo assay.

\section{In situ assessment of the antibacterial potential of thyme essential oil}

Thyme essential oil (TEO) was added to raw milk in order to test its effectiveness on total mesophilic aerobic flora (TAMF). Physico-chemical and bacteriological composition of used raw milk is presented in Table 2. Increasing TEO dose in raw milk significantly affected TAMF (Figure 1 ). Initial total bacterial count in raw milk was about $156 * 10^{3} \mathrm{cfu} / \mathrm{mL}$ and then reduced to 36.2 , 26.3 and $18 * 10^{3} \mathrm{cfu} / \mathrm{mL}$ using doses 1,2 and $3 \%$ respectively (Figure 1). These findings clearly indicate that TEO has proven to be remarkably effective on TAMF in raw milk. According to Ben Jemaa et al. (2016) by incorporating TEO or its nanoemulsion, bacterial growth in various contaminated milks has been positively controlled and physico-chemical and microbiological quality has been improved. In addition, Gammariello et al. (2008) reported that TEO inhibits microorganism's growth responsible for milk deterioration without affecting the dairy microflora. 
Fig 3 Yeasts and moulds evolution in cheese during storage at $4^{\circ} \mathrm{C}$.

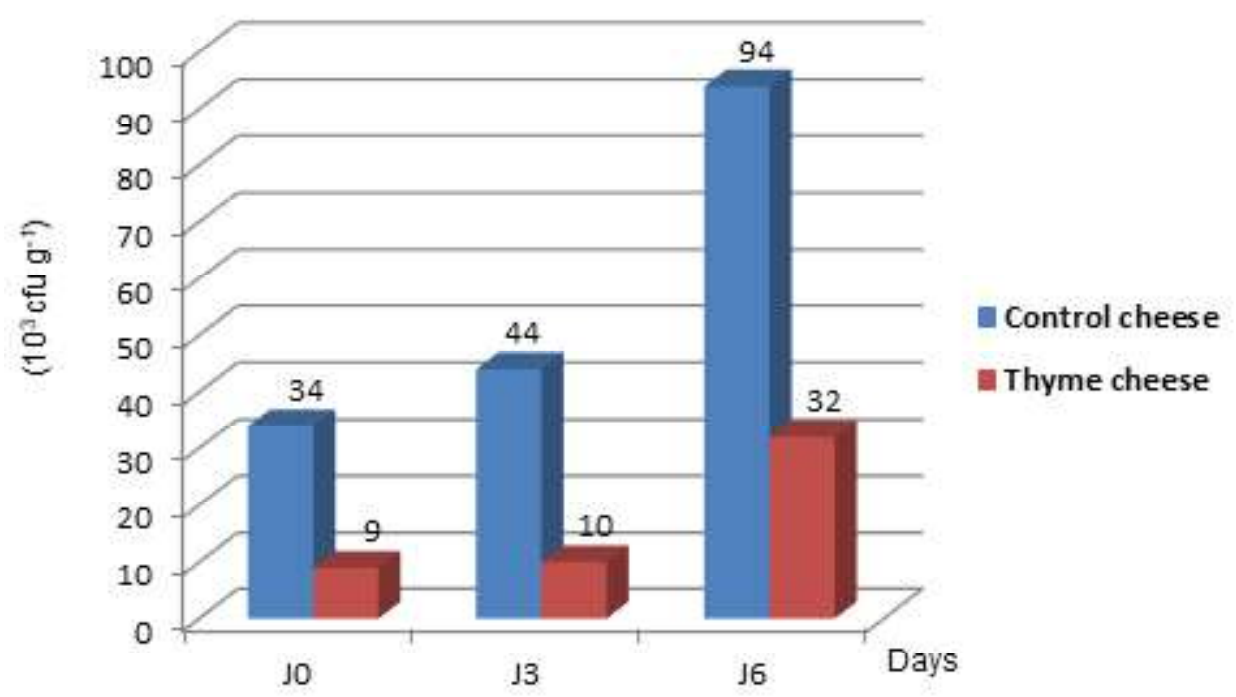

Fig 4 Sensory test results

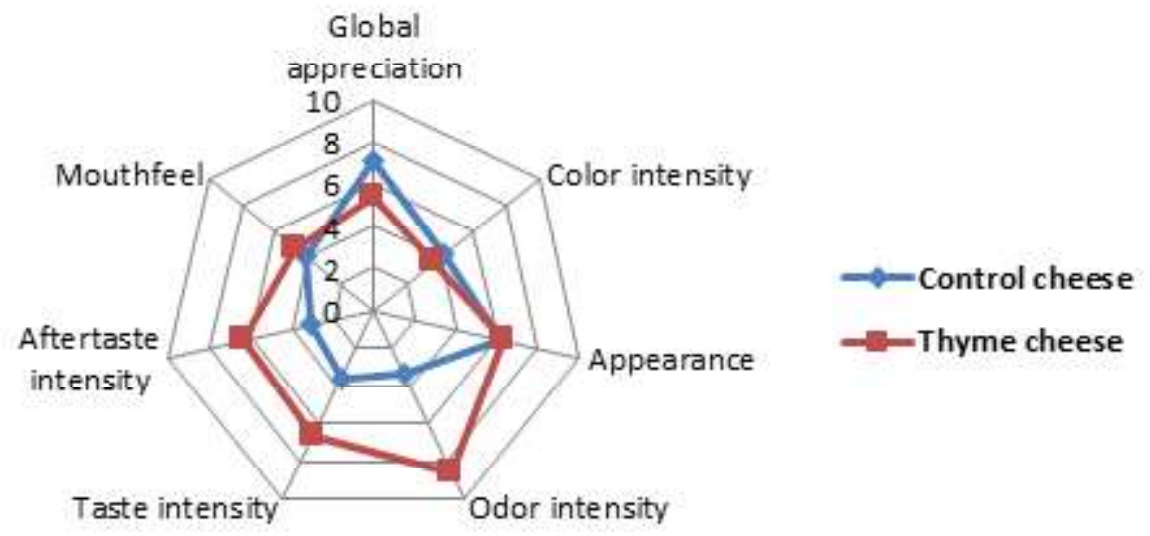

Table 2 Physico-chemical and bacteriological composition of raw milk

\begin{tabular}{lllllll}
\hline $\mathrm{MG}(\mathrm{g} / \mathrm{l})$ & $\mathrm{MP}(\mathrm{g} / \mathrm{l})$ & Lactose $(\mathrm{g} / \mathrm{l})$ & $\mathrm{pH}$ & $\mathrm{TAMF}(\mathrm{ufu} / \mathrm{mL}) * 10^{3}$ & $\mathrm{TC}(\mathrm{ufu} / \mathrm{mL})$ & $\mathrm{FC}(\mathrm{ufu} / \mathrm{mL})$ \\
\hline $48 \pm 0.05$ & $31.3 \pm 0.03$ & $47.8 \pm 0.03$ & $6.8 \pm 0.1$ & 156 & 0 & 0 \\
\hline
\end{tabular}

TAMF: total aerobic mesophilic flora; TC: total coliforms; FC: faecal coliforms.

\section{Assessment of cheese bacteriological quality during cold storage}

In vitro and in situ results led us to select the dose of $1 \%$ thyme essential oil (TEO) in farm cheese production, since it eradicated all tested pathogenic bacteria, as well as reducing total aerobic mesophilic flora (TAMF) to an acceptable level of about $36.2 * 10^{3}$ $\mathrm{ufc} / \mathrm{mL}$. In addition, dose of $1 \%$ TEO was chosen in order to reduce production cost of farm cheese, especially since natural essential oils are expensive. Figure 2 shows that during the first day of production, the TAMF of TEO cheese was significantly lower than that of control cheese $\left(60\right.$ and $159 * 10^{3} \mathrm{cfu} / \mathrm{g}$ respectively). Following 3 days of refrigerated storage, TAMF remained almost stable for cheese produced from TEO, while for control cheese, TAMF increased from 159 to $190 * 10^{3} \mathrm{cfu} / \mathrm{g}$. By the $6^{\text {th }}$ day of storage, TAMF had increased to $113 * 10^{3} \mathrm{cfu} / \mathrm{g}$ for
TEO cheese and $370 * 10^{3} \mathrm{cfu} / \mathrm{g}$ for control cheese. Therefore, thyme essential oil significantly reduced $(p<0.05)$ TAMF growth in cheese during refrigerated storage for 6 days.

Concerning yeasts and moulds, their count in TEO based farm cheese did not exceed $10^{*} 10^{3} \mathrm{cfu} / \mathrm{g}$ after 3 days of storage and $32 * 10^{3} \mathrm{cfu} / \mathrm{g}$ after 6 days of storage at $4{ }^{\circ} \mathrm{C}$ (Figure 3 ). However, for control cheese, yeasts and moulds have proliferated during storage and their count increased from 34 to $44 * 10^{3} \mathrm{cfu} / \mathrm{g}$ after 3 days of storage and to $94 * 10^{3} \mathrm{cfu} / \mathrm{g}$ after 6 days of storage (Figure $3)$. These results prove the effectiveness of TEO on yeasts and moulds in farm cheese even after six days of cold storage. These findings are in perfect agreement with study of Moro et al. (2013) which demonstrated that TEO has satisfactory antimicrobial 
activity against pathogens and spoilage microorganisms associated with cheese contamination. Similarly, Smith-Palmer et al. (2001) reported that TEO used at $1 \%$ concentration in low-fat cheese showed high effectiveness on L. monocytogenes and $S$. enteritidis and reduced their counts to harmless levels. Zantar et al. (2013) noted inhibition of unwanted germs, yeasts and moulds in flavored goat cheese using $0.05 \%$ TEO from the first week of production. In the same way, Burt (2004) reported that TEO has high antimicrobial activity in raw milk and produces healthy cheese. It was suggested by Carvalho et al. (2015) that essential oil doses used to control pathogenic bacteria in fermented dairy products, particularly in low-ripened cheeses, may be established with caution, due to potential negative effects on growth and survival of beneficial lactic acid bacteria used in such foods.

\section{Evaluation of sensory cheese quality}

Sensory evaluation revealed no difference $(p>0.05)$ between thyme essential oil (TEO) cheese and control cheese in terms of color, appearance and consistency (Figure 4). However, significant differences $(p<0.05)$ in taste, aftertaste and overall appreciation were observed between the two cheeses. If we consider the overall appreciation score, we can notice that the control cheese was more appreciated than the TEO cheese, but the latter was also liked by a large number of tasters. The strong aroma that characterizes TEO has had a negative impact on the final score attributed to TEO cheese by some tasters (Figure 4). Similar results have been reported by Zantar et al. (2013) indicating that goat cheese with $0.05 \%$ TEO was less appreciated by tasters than control cheese. In addition, Burt (2004) pointed out limited use of TEO in food products because of its intense aroma, which negatively affects taste and odor. According to Moro et al. (2015), the strong specific flavor of thyme oil, although used in small concentrations, can significantly affect sensory quality of dairy products and may result in their rejection. Gouvea et al. (2017) stated that acceptance of food products based on essential oils or plant extracts is extremely important, because having high antimicrobial effect is not enough if consumer doesn't approve it in a sensory way. Divergent results have been reported in several studies, including those of Leuschner and Ielsch (2003), Hayaloglu and Fox (2008), Gammariello et al. (2008), who all affirmed that TEO has been successfully incorporated into cheese and have been well accepted by consumers. Tayel et al. (2015) also confirmed that addition of TEO to cheeses resulted in good sensory acceptance. Gouvea et al. (2017) mentioned that general acceptance of cheeses with essential oils and plant extracts can be facilitated if consumers are already familiar with this type of products. To overcome taste problems, Gutierrez et al. (2008) proposed combination of different essential oils and extracts to have good antimicrobial effect without affecting product taste and smell.

\section{Conclusions}

Thyme essential oil can be used as an alternative solution for producing healthy farm cheese without needing heat treatment, while ensuring high nutritional value food product. However, the strong aroma characterizing this essential oil was not well appreciated by some tasters, which had a negative impact on the final score attributed to this cheese. This study remains an initiative that should be consolidated by further researches trying to combine other essential oils with thyme oil as a way to attenuate or completely eliminate the negative effects on taste.

\section{References}

AFNOR, (2009). V08-050. Food Microbiology. Coliforms enumeration through colony counting performed at $30^{\circ} \mathrm{C}$

AFNOR (2009). V08-060. Food Microbiology. Thermotolerant coliforms enumeration through colony counting performed at $44^{\circ} \mathrm{C}$

AFNOR (2013). ISO 4833-1. Food Microbiology. Horizontal method for microorganism enumeration - Part 1: Colony counting at $30^{\circ} \mathrm{C}$ by deep sowing technique. ISO 4833-1

Amirdivani S, Baba A (2011) Changes in yogurt fermentation characteristics, and antioxidant potential and in vitro inhibition of angiotensin - 1 converting enzyme upon the inclusion of peppermint, dill and basil. LWT - Food Sci Technol 44: 1458-1464

Antonio JT, Capellas M, Saldo J, Gervilla R, Guamis B (2002). Applications of high-hydrostatic pressure on milk and dairy products: a review. Innov Food Sci Emerg Technol 3: 295-307

Balny C, Masson P (1993) Effects of high-pressure on proteins. Food Rev Int 9: 611-628

Ben Jemaa M, Fellah H, Neves MA, Isoda H, Nakajima M, Ksouri R (2016) Quality preservation of deliberately contaminated milk using thyme free and nonemulsified essential oils. Food Chem 217: 726734

Burt SA, Reinders RD (2003) Antibacterial activity of selected plant essential oils against Escherichia coli O157:H7. Lett Appl Microbiol 36: $162-167$

Burt S (2004) Essential oils: their antibacterial properties and potential applications in foods - a review. Int J Food Microbiol 94: 223-253

Calo JR, Crandall PG, O'Bryan CA, Ricke SC (2015) Essential oils as antimicrobials in food systems - A review. Food Control 54: 111119

Cameron M, McMaster LD, Britz TJ (2009) Impact of ultrasound on dairy spoilage microbes and milk components. Dairy Sci Technol 89: $83-98$

Carvalho RJ, de Souza GT, Honorio VG, de Sousa JP, da Conceiçao ML, Maganani M de Souza EL (2015) Comparative inhibitory effects of Thymus vulgaris L. essential oil against Staphylococcus aureus, Listeria monocytogenes and mesophilic starter co-culture in cheesemimicking models. Food Microbiol 52: 59-65

Chandan RC (2003) Soft and special varieties. In: Cavellaro B, Trugo LC, Finglas PM (eds). Encyclopedia of Food Sciences and Nutrition Vol 2 New York: Academic Press, pp. 1093-1098

Cox SD, Mann CM, Markham JL, Bell HC, Gustafson JE, Warmington JR, Wyllie SG (2000). The mode of antimicrobial action of the essential oil of Melaleuca alternifolia (tea tree oil). J Appl Microbiol 88: 170175

Cutter CN (2000) Antimicrobial effect of herb extracts against Escherichia coli O157:H7, Listeria monocytogenes, and Salmonella typhimurium associated with beef. J Food Protect 63: 601- 607 
Datta N, Deeth HC (1999). High pressure processing of milk and dairy products. Aust J Dairy Technol 54: 41

Evans MR, Roberts RJ, Ribeiro CD, Gardner D, Kembrey D (1996) A milkborne campylobacter outbreak following an educational farm visit. Epidemiol Infect 117: 457-462

Fahey T, Morgan D, Gunneburg C, Adak GK, Majid F, Kaczmarski E (1995) An out-break of Campylobacter jejuni enteritis associated with failed milk pasteurization. J Infect 31: 137-143

Fleming DW, Cochi SL, MacDonald KL, Brondum J, Hayes PS, Plikaytis BD, Holmes MB, Audurier A, Broome CV, Reingold AL (1985) Pasteurized milk as a vehicle of infection in an outbreak of listeriosis. N Engl J Med 312: 404-407

Gammariello D, Di Giulio S, Conte A, Del Nobile MA (2008) Effects of natural compounds on microbial safety and sensory quality of Fior di Latte cheese, a typical Italian cheese. J Dairy Sci 91: 4138-4146

Gouvea FDS, Rosenthal A, Ferreira AREH (2017) Plant extract and essential oils added as antimicrobials to cheeses: a review. Ciênc Rural 47: 19

Gravani R (1999) Incidence and control of Listeria in food-processing facilities. In: Listeria listeriosis and food safety, 2nd ed. Ryser, E.T., and E.H. Marth (ed.), Marcel Decker, New York, pp. 657-709

Gutierrez J, Barry-Ryan C, Bourke P (2008) The antimicrobial efficacy of plant essential oil combinations and interactions with food ingredients. Int J Food Microbiol 124: 91-97

Gutierrez J, Barry-Ryan C, Bourke P (2009) Antimicrobial activity of plant essential oils using food model media: efûcacy, synergistic potential and interaction with food components. Food Microbiol 26: $142-150$

Hammer KA, Carson CF, Riley TV (1999) Antimicrobial activity of essential oils and other plant extracts. J Appl Microbiol 86: 985-990

Hayaloglu AA, Fox PF (2008) Cheeses of Turkey: 3. Varieties containing herbs or spices. Dairy Sci Technol 88: 245-256

Helander IM, Alakomi HL, Kala KL, Sandholm TM, Pol I, Smid EJ, Gorris LGM, Von AW (1998) Characterization of the action of selected essential oil components on Gram-negative bacteria. J Agri Food Chem 46: 3590-3595

Jones FA (1996) Herbs - useful plants. Their role in history and today. Eur J Gastroenterol Hepatol 8: 1227-1231

Leuschner RGK, Ielsch V (2003) Antimicrobial effects of garlic, clove and red hot chilli on Listeria monocytogenes in broth model systems and soft cheese. International Journal of Food Sci Nutr 54: 127-133

Lis-Balchin M, Deans SG (1997) Bioactivity of selected plant essential oils against Listeria monocytogenes. J Appl Bact 82: 759-762
Manju G, Chand R, Suman R (2017) Combination of trans-cinnamaldehyde and eugenol with nisin for inactivation of L. monocytogenes. Indian J Dairy Sci 70: 411-420

Mauron J (1981) The Maillard reaction in food: a critical review from the nutritional standpoint. Progr Food Nutr Sci 5: 5-35

Moro A, Librán CM, Berruga MI, Zalacain A, Carmona M 2013 Mycotoxicogenic fungal inhibition by innovative cheese cover with aromatic plants. J Sci Food Agric 93: 1112-1118

Moro A, Librán CM, Berruga MI, Carmona M, Zalacain A (2015) Dairy matrix effect on the transference of rosemary essential oil compounds during cheese making. J Sci Food Agric 95: 1507-1513

Oliveira AA, Segovia JFO, Sousa VYK, Mata ECG, Gonçalves MCA, Bezerra RM, Junior, POM, Kanzaki LIB (2013) Antimicrobial activity of Amazonian medicinal plants. Springer Plus 2: 371

Paster N, Juven BJ, Shaaya E, Menasherov M, Nitzan R, Weisslowicz H, Ravid U (1990) Inhibitory effect of oregano and thyme essential oils on moulds and foodborne bacteria. Lett Appl Microbiol 11: 3337

Reynolds JEF (1996) Martindale - the Extra Pharmacopoeia 31st edn. London: Royal Pharmaceutical Society of Great Britain

Smania AJ, Delle Monache F, Smania EFA, Cuneo RS (1999) Antibacterial Activity of Steroidal Compounds Isolated from Ganoderma applanatum. Int J Med Mushrooms 1: 325-330

Smith-Palmer A, Stewart J, Fyfe L (2001) The potential application of plant essential oils as natural food preservatives in soft cheese. Food Microbiol 18: 463-470

Tayel AA, Hussein H, Sorour NM, El-Tras WF (2015) Foodborne pathogens prevention and sensory attributes enhancement in processed cheese via flavoring with plant extracts. J Food Sci 80: 2886-2891

Tiwari BK, Valdramidis VP, O'Donnell CP, Muthukumarappan K, Bourke P, Cullen PJ (2009). Application of natural antimicrobials for food preservation. J Agric Food Chem 57: 5987-6000

Van Kessel JS, Karns JS, Gorski L, McCluskey BJ, Perdue ML (2004) Prevalence of Salmonellae, Listeria monocytogenes and fecal coliforms in bulk tank milk on U.S. dairies. J Dairy Sci 87: 2822 2830

WHO (2002) World Health Organization Report. Food safety and foodborne illness. World Health Organization Fact sheet 237, revised January 2002. Geneva

Zantar S, Zerrouk HM, Zahar M, Said B, Notfia Z, Laglaoui A, Larbi T, Chentouf M (2013) Effect of using essential oils (thyme, rosemary, oregano and myrtle) on physico-chemical, microbiological and sensory properties of fresh and semi-ripened goat's cheese .Options Méditerraniénnes, 108: 183-190 